\begin{tabular}{|c|c|c|c|c|}
\hline $\begin{array}{c}\text { Focus: Jurnal } \\
\text { Pekerjaan Sosial }\end{array}$ & ISSN: $2620-3367$ & Vol. 2 No: 2 & Hal: $245-256$ & Desember 2019 \\
\hline
\end{tabular}

\title{
MEMAHAMI PENGUNGKAPAN KEKERASAN SEKSUAL TERHADAP ANAK (UNDERSTANDING DISCLOSURE OF SEXUAL VIOLENCE AGAINST CHILDREN)
}

\author{
Binahayati Rusyidi \\ Departemen Kesejahteraan Sosial, FISIP UNPAD \\ binahayati@unpad.ac.id \\ Hetty Krisnani \\ Departemen Kesejahteraan Sosial, FISIP UNPAD
}

\section{LATAR BELAKANG}

Kekerasan terhadap anak merupakan masalah global yang terjadi baik di negara maju dan negara berkembang. Sebuah kajian UNICEF yang dipublikasikan pada tahun 2014 memperkirakan 120 juta anak perempuan berusia di bawah 20 tahun telah mengalami pemaksaan hubungan seksual atau bentuk pemaksaan seksual lainnya pada satu waktu dalam kehidupan mereka. Anak laki-laki juga dipandang berisiko mengalami kekerasan seksual walaupun dalam derajat yang lebih rendah dibandingkan anak perempuan (Unicef, 2014). Merujuk pada berbagai laporan penelitian lembaga pembangunan internasional, World Health Organization (2006) menggarisbawahi bahwa pada tahun 2000 sekitar 3 juta anak dipaksa atau diiming-imingi menjalani eksploitasi seksual sebagai pekerja seks, pornografi atau korban trafficking. Penelitian mengenai kekerasan anak yang dilakukan Unicef di 38 negara miskin dan berkembang menemukan bahwa hampir 17 juta perempuan dewasa mengaku pernah mengalami kekerasan seksual semasa kecil.
Kekerasan seksual merupakan salah satu bentuk paling umum perlakuan salah terhadap anak yang menimbulkan dampak serius terhadap korban dan masyarakat sehingga perlu dicegah dan ditangani dengan tepat. Pengungkapan dan pelaporan tindak kekerasan seksual terhadap anak merupakan langkah penting untuk melindungi anak dari tindak kekerasan lanjutan dan memastikan bahwa korban mendapatkan intervensi yang dibutuhkan secepatnya untuk menanggulangi dampak negatif yang dialami akibat tindak kekerasan seksual yang dialaminya. Hal ini sejalan dengan pernyataan Alaggia, Collin-Vezina dan Lateef (2016) sebagai berikut:

Timely access to supportive and therapeutic resources for child sexual abuse (CSA) survivors can mitigate risk to the health and mental health well-being of children, youth, and adults. Identifying and understanding factors that promote or inhibit CSA disclosures have the potential to facilitate earlier disclosures, assist survivors to receive services without delay, and potentially prevent further sexual victimization (h.1) 


\begin{tabular}{|c|c|c|c|c|}
\hline $\begin{array}{c}\text { Focus: Jurnal } \\
\text { Pekerjaan Sosial }\end{array}$ & ISSN: $2620-3367$ & Vol. 2 No: 2 & Hal: $245-256$ & Desember 2019 \\
\hline
\end{tabular}

Pengungkapan dan pelaporan juga memfasilitasi terjadinya tindakan hukum atas pelaku. Pelaporan juga membantu penyediaan data yang akurat terkait prevalensi dan tingkat keparahan kekerasan terhadap anak yang sebenarnya dapat dapat digunakan untuk membangun strategi penanggulangan masalah.Namun demikian, para peneliti dan ahli menemukan bahwa penungkapan dan pelaporan bukanlah hal yang mudah dilakukan manakala seseorang mengalami atau menyaksikan/mengetahui adanya tindak kekerasan seksual terhadap anak. Kondisi ini merupakan salah satu kendala yang menyebabkan kesulitan mendapatkan informasi yang valid mengenai besaran dan tingkat keparahan kekerasan seksual terhadap anak.

Studi tentang kekerasan terhadap anak di 38 negara oleh Unicef (2014) menemukan bahwa sebagian besar anak korban kekerasan seksual menunda mengungkapkan kekerasan yang mereka alami-kadang-kadang setelah kejadian berlangsung sangat lama. Temuann studi Unicef di beberapa negara Afrika misalnya menunjukkan bahwa antara $23 \%$ sampai dengan $34 \%$ perempuan dan laki-laki yang pernah mengalami kekerasan seksual saat kecil tidak pernah melaporkan peristiwa yang dialami atau mencari bantuan kepada siapapun untuk mendapatkan perlindungan atau bantuan karena berbagai alasan.

Artikel ini bertujuan untuk memahami faktor-faktor yang mempengaruhi pengungkapan kekerasan seksual yang dialami anak. Para ahli dan peneliti mengkategorikan pengungkapan (disclosure) menjadi dua kelompok yaitu purposeful disclosure dan accidental disclosure. Purposeful disclosure didefinisikan sebagai "an intentional and deliberate revelation of the abuse with clear intent of revealing its existence" dan accidental disclosure adalah "a statement made without forethought or intent to reveal the abusive relationship" (Mian, Klajner-Diaond, Labaron, \& Winder, 1986, h. 226). Pembahasan akan dimulai dengan mendiskusikan konseptualisasi dan karakteristik kekerasan seksual terhadap anak dan dampak negatif yang disebabkan oleh tindak kekerasan tersebut. Selanjutnya diskusi mengenai faktor-faktor yang mempengaruhi pengungkapan dan pelaporan kekerasan seksual terhadap anak akan dipandu oleh kerangka teori ekologi dengan mempertimbangkan beragam faktor pada berbagai tingkat lingkungan yang berbeda. Kajian dilakukan dengan dengan menganalisa dokumen berupa artikel yang dipublikasi pada jurnal internasional bereputasi dan laporan-laporan lembaga pembangunan yang fokus pada kesejahteraan dan perlindungan anak.

\section{PEMBAHASAN}

\section{Karakteristik Kekerasan Seksual Terhadap Anak}

Definisi Kekerasan Terhadap Anak telah mengalami pengembangan sejak pertama kali dikonseptualisai secara formal dalam hukum internasional melalui Konvensi Hak Anak tahun 1989. Pasal 19 Konvensi Hak Anak mendefinisikan kekerasan terhadap anak sebagai "all forms of physical or mental violence, injury and abuse, neglect or negligent treatment, 


\begin{tabular}{|c|c|c|c|c|}
\hline $\begin{array}{c}\text { Focus: Jurnal } \\
\text { Pekerjaan Sosial }\end{array}$ & ISSN: $2620-3367$ & Vol. 2 No: 2 & Hal: $245-256$ & Desember 2019 \\
\hline
\end{tabular}

maltreatment or exploitation, including sexual abuse" yang dialami oleh seorang individu yang berusia di bawah 18 tahun. Sementara itu dalam World Report on Violence and Health tahun 2002, World Health Organization memperjelas konsep kekerasan terhadap anak secara lebih terperinci dengan menekankan kekerasan sebagai tindakan yang disengaja dan menimbulkan kerugian dan dampak negatif terhadap korban. Menurut Organisasi Kesehatan Dunia (2002) kekerasan terhadap anak adalah "the intentional use of physical force or power, threatened or actual, against a child, by an individual or group, that either results in or has a high likelihood of resulting in actual or potential harm to the child's health, survival, development or dignity'.

Organisasi Kesehatan Dunia (2002) mendefinisikan kekerasan seksual sebagai:[...] any sexual act, attempt to obtain a sexual act, or other act directed against a person's sexuality using coercion, by any person regardless of their relationship to the victim, in any setting. It includes rape, defined as the physically forced or otherwise coerced penetration of the vulva or anus with a penis, other body part or object ( $h$ : 149). Sementara itu, Unicef (2014: h.4) memberikan penjelasan yang lebih rinci mengenai kekerasan seksual terhadap anak yang mencakup tindakan tujuan eksploitatif maupun non-eksploitatif. Tindakan pemaksaan seksual tersebut dapat berupa ) Mengiming-iming atau merayu atau memaksa anak untuk terlibat dalam aktivitas seksual yang secara bertentangan dengan hukum atau menimbulkan dampak negative terhadap perkembangan anak; b) Eksploitasi anak dalam aktivitas seksual komersial; c) Menggunakan anak dalam tayangan berupa suara atau gambar yang merupakan tindak kekerasan seksual dan d) pelacuran anak, budak seks, eksploitasi seksual anak dalam perjalanan dan wisata, perdagangan anak untuk tujuan eksploitasi seksual di dalam dan luar negeri, penjualan anak untuk tujuan seksual dan pernikahan paksa; e) pelecehan seksual terhadap anak secara verbal dan atau emosional. Aktivitas seksual didefinisikan sebagai tindakan kekerasan jika dilakukan terhadap seorang anak oleh individu lainnya dengan menggunakan kekuasan, ancaman dan cara-cara memaksa lainnya.

Kekerasan seksual terhadap anak dapat terjadi dalam kondisi masyarakat yang normal dan relative stabil maupun dalam konteks darurat. Unicef (2014) menggarisbawahi bahwa dalam kondisi darurat seperti bencana alam, konflik, peperangan dan pengungsian, resiko anak untuk mengalami beberapa bentuk perlakuan salah secara seksual meningkat, termasuk korban perkosaan, eksploitasi dan perdagangan anak. Kondisi kedaruratan berisiko menyebabkan anak kehilangan atau terpisah dari keluarganya sehingga kurang terlindungi, kondisi penampungan atau pengungsian yang tidak layak dengan privasi yang terbatas, melemahnya sistem penegakan hukum, rusaknya tatanan struktur sosial serta meningkatnya stress dapat memicu semakin tingginya kerentanan anak sebagai sasaran tindak kekerasan seksual.

Pelaku kekerasan seksual terhadap anak terdiri atas 2 kelompok: pihak yang dikenal baik oleh korban seperti orangtua, kerabat, pengasuh, pacar, teman sepermainan, guru, pelatih dan sebagainya atau pihak yang tidak dikenal baik atau sama sekali asing bagi korban. Ini berarti bahwa kekerasan seksual dapat terjadi di wilayah-wilayah yang dianggap aman bagi anak seperti rumah, sekolah, lembaga 


\begin{tabular}{|c|c|c|c|c|}
\hline $\begin{array}{c}\text { Focus: Jurnal } \\
\text { Pekerjaan Sosial }\end{array}$ & ISSN: $2620-3367$ & Vol. 2 No: 2 & Hal: $245-256$ & Desember 2019 \\
\hline
\end{tabular}

pengasuhan, lingkungan ketetanggaan, tempat kerja ataupun wilayah-wilayah public yang kurang dikenal anak seperti lokasi wisata, pengungsian akibat bencana dan wilayahwilayah umum lainnya. Namun demikian, Studi oleh United Nations Secretary-General (2006) menemukan bahwa di sebagian besar negara, kekerasan seksual terhadap anak laki-laki maupun perempuan paling sering terjadi oleh seseorang yang dikenal oleh anak dan keluarganya.

Walaupun kekerasan seksual dapat terjadi terhadap setiap anak karena berbagai keterbatasan fisik, mental dan sosial yang mereka miliki dibandingkan orang dewasa, berbagai penelitian menemukan ada pola-pola perlakuan salah secara seksual yang relative berbeda yang rentan dialami anak sesuai dengan tahap perkembangannya. Karakteristik lingkungan dan aktivitas anak sesuai dengan usia perkembangan sosial biologisnya memiliki peran membentuk factor resiko bagi anak meskipun bukan menjadi satu-satunya faktor. Unicef (2014) menegaskan hal ini sebagai berikut:

"No one factor can adequately explain why children are at risk of sexual victimization, although it is clear they are more vulnerable to abuse due to their age. In general, children have less experience, knowledge, maturity and, in many cases, physical strength than adults, which puts them at increased risk of being perceived as easy targets. Although children of every age are vulnerable, the specific risks they may be exposed to are likely to vary across developmental stages. For instance, younger children may be particularly vulnerable to abuse by adults or other caregivers they trust and on whom they depend - at home or in other care settings where they are likely to spend a majority of their time. Adolescents, on the other hand, may be more prone to victimization outside the home through exposure to both strangers and peers, the latter within the context

of both friendship and intimate relationships" (h: 61).

\section{Dampak Kekerasan Seksual Terhadap Anak}

Pada prinsipnya, dampak kekerasan seksual terhadap anak dapat dibagi atas 2 kelompok utama yaitu dampak terhadap korban dan dampak terhadap masyarakat. Artikel ini menekankan pembahasan pada dampak kekerasan seksual terhadap anak terhadap korban. Terkait dengan dampak di tingkat individual, kompilasi berbagai hasil penelitian lintas budaya di tingkat global (WHO, 2002; Unicef, 2014; Hillis dkk., 2016) menunjukkan bahwa kekerasan seksual terhadap anak menghambat semua aspek perkembangan anak baik secara fisik, psikologis dan sosial. Kekerasan seksual juga berdampak negatif terhadap masyarakat, salah satunya ditunjukkan dengan tingginya kerugian dan beban ekonomi yang ditimbulkan oleh dampak kekerasan terhadap korban mapun masyarakat secara umum seperti dijabarkan di bawah ini.

Kompilasi berbagai hasil penelitian di berbagai negara menunjukkan bahwa kekerasan seksual di masa kanak-kanak dapat menyebabkan luka atau kecacatan fisik, keterpaparan terhadap penyakit menular seksual dan HIV serta kehamilan yang tidak diinginkan. Mengingat perempuan dewasa dan anak perempuan lebih berisiko mengalami kekerasan seksual dibandingkan anak laki-laki maka 


\begin{tabular}{|c|c|c|c|c|}
\hline $\begin{array}{c}\text { Focus: Jurnal } \\
\text { Pekerjaan Sosial }\end{array}$ & ISSN: $2620-3367$ & Vol. 2 No: 2 & Hal: $245-256$ & Desember 2019 \\
\hline
\end{tabular}

pencegahan tindak kekerasan seksual terhadap perempuan menjadi strategi kunci berbagai lembaga internasional untuk mencegah HIV pada generasi mendatang.

Anak yang menjadi korban kekerasan seksual juga lebih memiliki resiko untuk mengalami berbagai gangguan perilaku dan kesehatan mental. Termasuk di dalamnya perilaku yang menyakiti diri sendiri termasuk gangguan seperti bulimia dan anorexia, percobaan bunuh diri, dan sebagainya. Berbagai penelitian secara konsisten menunjukkan bahwa anak korban kekerasan seksual berpeluang besar mengalami beragam gangguan mental seperti gejala depresi, gangguan panik, keceasan serta mimpi buruk, khususnya di kalangan anak berusia muda. Selanjutnya, perasan malu, keterpaksaan untuk menyimpan rahasia atas kejadian yang dialmi, dan stigma yang dilekatkan pada korban menyebabkan anak terpaksa mengisolasi diri atau berjuang keras melakukan coping supaya tetap berfungsi normal. Semakin sering dan semakin parah tindak kekerasan seksual yang dialami korban maka semakin tinggi resiko korban untuk mengalami dampak negatif gangguan kesehatan mental yang bertahan dalam jangka waktu panjang.

Kompilasi berbagai penelitian juga menggarisbawahi potensi kerugian sosial jangka panjang yang dialami oleh anak yang menjadi korban kekerasan seksual. Anak-anak yang menjadi korban kekerasan seksual oleh seseorang dekat, kenal atau percayai berpeluang membangun persepsi dan perasaan tidak aman atau mengembangkan kelekatan yang kacau terhadap orang lain. Akibatnya mereka dapat mengalami kesulitan membangun hubungan sosial di masa dewasa. Korban berpeluang mengalami perasaan ketakutan yang tinggi, terancam atau merasa dibenci. Sebagai tindakan pemecahan masalah (coping) atas beban psikologis dan sosial yang mereka tanggung, korban umumnya memilih untuk melarikan diri dari rumah, bolos sekolah, terlibat dalam aktivitas seksual berisiko, menggunakan NAPZA, yang pada dasarnya semakin membuat mereka terisolasi secara sosial dan memperbesar resiko mereka untuk mengalami bentuk eksploitasi atau kekerasan yang lain. Berbagai penelitian menemukan bahwa dibandingkan dengan anakanak yang bukan korban, setelah dewasa, anakanak yang mengalami kekerasan seksual lebih berisiko melanggar hukum serta mengalami revictimization seperti menjadi korban kekerasan dalam hubungan inti (khususnya perempuan), mengalami eksploitasi seksual.

Hillis dkk. (2016) secara khusus menyorot hasil berbagai penelitian yang menunjukkan kekerasan di masa kecil berasosiasi dengan berbagai penyakit serius yang muncul pada saat korban berusia dewasa. Keterpaparan terhadap kekerasan di usia kanak-kanak dan ketidakberfungsian keluarga konsisten berasosiasi dengan meningkatnya resiko mengalami empat penyakit serius yang dapat menimbulkan kematian yaitu penyakit carviovascular, kanker, penyakit paru-paru kronis dan diabetes. Dukungan berbagai penelitian kesehatan menjelaskan keterkaitan antara 


\begin{tabular}{|c|c|c|c|c|}
\hline $\begin{array}{c}\text { Focus: Jurnal } \\
\text { Pekerjaan Sosial }\end{array}$ & ISSN: $2620-3367$ & Vol. 2 No: 2 & Hal: $245-256$ & Desember 2019 \\
\hline
\end{tabular}

kekerasan di masa kanak-kanak dengan resiko penyakit kronis di masa dewasa. Kekerasan di masa kecil menyebabkan stress traumatic pada korban yang selanjutnya mengganggu bentuk otak, daya tahan tubuh, sistem metabolisme dan respon terhadap peradangan/infeksi. Dengan demikian, keterpaparan terhadap stress traumatic di masa kecil meninggalkan bekas yang bertahan lama dan menimbulkan dampak negatif pada sebagian sistem dasar biologis manusia yang dapat mengganggu sistem genetik yang pada gilirannya dapat mempengaruhi resiko mengalami penyakit kronis tertentu.

Kekerasan seksual juga mempengaruhi kondisi kesejahteraan ekonomi korban setelah dewasa. Studi jangka panjang terhadap anakanak yang mengalami kekerasan fisik dan seksual dan kasusnya ditangani oleh sistem pengadilan di Amerika Serikat menemukan bahwa pada saat dewasa (usia 30 atau 40-an), para korban lebih banyak yang menganggur dan tidak memiliki asset seperti rumah, kendaraan, akun bank atau saham dibandingkan mereka yang bukan korban. Para korban juga cenderung mengalami berkurangnya potensi pendapatan sekitar 5000 dollar US per tahun (Currie \& Widom, 2010).

\section{Faktor-Faktor Yang Mempengaruhi Pengungkapan Dan Pelaporan Kekerasan Seksual Terhadap Anak}

Pengungkapan dan pelaporan merupakan bagian dari strategi pencarian bantuan (help-seeking) yang dapat dilakukan oleh anak yang mengalami kekerasan seksual. Namun demikian, seperti diungkapkan sebelumnya, dibandingkan dengan kekerasan fisik, anak korban kekerasan seksual jauh lebih jarang mengungkapkan atau melaporkan kasusnya kepada pihak lain dalam rangka mendapatkan bantuan perlindungan dan layanan penanganan dampak/masalah. Pendekatan ekologi memandang berbagai level lingkungan yang berbeda dalam lingkungan kehidupan anak mempengaruhi pengungkapan atau pelaporan tindak kekerasan seksual yang dialami anak. Meskipun masing-masing level lingkungan dapat dibedakan satu sama lain, dalam realitas semuanya saling mempengaruhi untuk menciptakan faktor yang mendorong atau memfasilitasi pengungkapan dan pelaporan dan sebaliknya mengjadi faktor penghambat.

\section{Individual}

Pada level individual, usia dan jenis kelamin merupakan prediktor yang mempengaruhi penundaan atau penolakan pengungkapan pengalaman kekerasan seksual (Unicef 2014; Alaggia dkk. 2017). Hasil metaanalisis oleh Alaggia dkk. (2017) menunjukkan bahwa anak yang berusia lebih muda dan anak laki-laki jarang mengungkapkan pengalaman kekerasannya. Anak berusia lebih muda mungkin terhambat mengungkapkan pengalamannya karena ketidakmampuan mendefinisikan pengalamannya sebagai tindak kekerasan yang melanggar norma sosial dan hukum atau karena keterbatasan bahasa untuk mengungkapkannya. Anak yang berusia muda umumnya berisiko mengalami manipulasi, paksaan dan grooming oleh orang dewasa di sekitarnya atau teman- 


\begin{tabular}{|c|c|c|c|c|}
\hline $\begin{array}{c}\text { Focus: Jurnal } \\
\text { Pekerjaan Sosial }\end{array}$ & ISSN: $2620-3367$ & Vol. 2 No: 2 & Hal: $245-256$ & Desember 2019 \\
\hline
\end{tabular}

teman sepermainan yang lebih tua karena kekurangmampuan menyadari motf pelaku atau kejadian kekerasan yang dialaminya. Anak-anak mungkin mengungkapkan pengalamannya secara tidak langsung atau tidak sengaja, terkadang dengan melakukan perilaku yang negatif sebagai bentuk dari coping yang mereka lakukan.

Sebaliknya, peluang pengungkapan kekerasan seksual di usia anak meningkat seiring bertambahnya usia, terutama dilakukan di saat dewasa. Karena itu penting bagi orang dewasa untuk peduli terhadap anak manakala mereka menunjukkan perubahan perilaku dan emosi yang tidak biasa yang mungkin merupakan indikasi terjadinya kekerasan yang tidak dapat mereka ungkapkan. Sementara itu anak laki-laki mengalami hambatan karena norma-norma jender terkait maskulinitas memperkuat kecenderungan anak laki-laki yang menjadi korban untuk menyalahkan diri sendiri. Ketika mengalami kekerasan seksual oleh laki-laki lain, anak laki-laki takut dipandang sebagai homoseksual sehingga dapat memunculkan stigma dan isolasi sosial. Adanya keyakinan di dalam masyarakat bahwa anak laki-laki jarang menjadi korban kekerasan seksual juga menjadi faktor penghambat pengungkapan karena kekhawatiran korban dianggap berbohong dan tidak dipercaya lingkungannya.

Alaggia dkk. (2017) juga menemukan bahwa hubungan dengan perpetrator menjadi faktor yang mempengaruhi pengungkapan kejadian kekerasan seksual. Jika pelaku adalah anggota keluarga atau figur seperti keluarga, maka peluang pengungkapan menurun dan sebaliknya jika pelaku tidak tinggal bersama korban maka pengungkapan kejadian lebih mungkin dilakukan. Para peneliti juga menemukan bahwa aspek internal psikologis anak seperti perasan malu, perasaan menyalahkan diri sendiri dan ketakutan terhadap ancaman pelaku atau kekhawatiran menimbulkan masalah dalam keluarga karena pelibatan aparat hukum dalam penanganan kasus dapat menghambat anak mengungkapkan kejadian kekerasan yang dialaminya.

Fontes \& Plummer (2010) menyorot karakteristik hubungan pelaku dan korban kekerasan seksual dapat menghambat kemampuan anak untuk memahami kejadian yang dialaminya secara tepat dan menghambat pengungkapan kejadian kepada lingkungan sekitar. Dalam banyak kasus, pelaku melakukan grooming kepada korban sehingga korban menjadi terbiasa dengan peningkatan bentuk perilaku kekerasan seksual dari semula berupa sentuhan yang tidak memiliki makna apa-apa menjadi insiden kekerasan. Sehingga pada saat anak mengalami bentuk kekerasan seksual yang lebih serius maka mereka merasa bertanggungjawab atau bersalah karena tidak melaporkan kejadian yang dialaminya kepada orang-orang yang mereka percaya sejak awal dan anak mungkin terbiasa dengan bentuk perilaku tersebut sehingga memandangnya sebagai bentuk kejadian yang normal atau ada 


\begin{tabular}{|c|c|c|c|c|}
\hline $\begin{array}{c}\text { Focus: Jurnal } \\
\text { Pekerjaan Sosial }\end{array}$ & ISSN: $2620-3367$ & Vol. 2 No: 2 & Hal: $245-256$ & Desember 2019 \\
\hline
\end{tabular}

kemungkinan menikmati aspek tertentu dari hubungannya dengan pelaku.

\section{Keluarga}

Penelitian Unicef tentang kekerasan terhadap anak di 38 negara menemukan bahwa sebagian besar perempuan korban kekerasan seksual di masa kanak-kanak mencari bantuan atau mengungkapkan kasusnya kepada keluarga mereka (Unicef, 2014). Ini berarti keluarga memegang peranan penting untuk dapat membantu korban atau sebaliknya menghambat korban mendapatkan bantuan. Hal ini ditunjukkan dalam meta- analisis yang dilakukan Alaggia dkk. (2017) yang menemukan bahwa keluarga dapat menjadi faktor pendorong atau penghambat bagi korban kekerasan seksual untuk mendapatkan bantuan.

Hubungan dalam keluarga menjadi faktor yang dapat mendorong dan menghambat pengungkapan kekerasan seksual. Alaggia dkk. (2017) menunjukkan bahwa di tingkat keluarga, faktor-faktor yang dapat menghambat pengungkapan kekerasan termasuk keluarga yang didasarkan pada struktur patriarki, menjalani pembagian peran jender yang kaku, memiliki hambatan komunikasi, mengalami bentuk kekerasan dalam rumah tangga lainnya dan terisolasi. Sebaliknya keluarga yang memilki hubungan yang sehat yang ditunjukkan dengan adanya hubungan yang suportif antara anak dan keluarga mendorong anak untuk mengungkapkan tindak kekerasan seksual yang dialaminya.
Fontes dan Plummer (2010) juga memandang penting rekasi lingkungan sekitar. Jika orang dewasa di sekitar anak, termasuk anggota keluarga memberikan respon yang tidak tepat atau tidak mendukung, termasuk memandang enteng pengalaman/cerita anak, tidak mempercayai anak, menyalahkan anak atau melabrak pelaku, maka anak yang menjadi korban mungkin merasa tidak mendapat dukungan untuk menyelesaikan masalah yang dihadapinya. Apalagi jika konfrontasi dimanfaatkan oleh pelaku untuk membela diri dan menyalahkan anak, maka hal tersebut dapat menjadi hukuman dan menyebabkan penderitaan lebih lanjut bagi korban.

Studi oleh UN Sectetary General (2006) menekankan bahwa sikap dan perlakuan keluarga justru dapat menyebabkan anak korban tindak kekerasan seksual tidak mendapat bantuan yang seharusnya sehingga berpotensi mengalami dampak negatif yang lebih buruk. Termasuk di dalamnya sikap diam keluarga jika kekerasan seksual dilakukan oleh pasangan intim, anggota keluarga atau anggota masyarakat yang berpengaruh (misal: majikan, guru, petugas penegak hukum, tokoh atau pimpinan masyarakat). Kurangnya kesadaran keluarga mengenai tanda-tanda kekerasan yang dialami anak serta kurangnya pemahaman tentang proses pelaporan kepada lembaga perlindungan anak yang berwenang serta persepsi bahwa pelaporan justru akan menyebabkan masalah menjadi lebih rumit juga termasuk faktor-faktor yang menghambat 


\begin{tabular}{|c|c|c|c|c|}
\hline $\begin{array}{c}\text { Focus: Jurnal } \\
\text { Pekerjaan Sosial }\end{array}$ & ISSN: $2620-3367$ & Vol. 2 No: 2 & Hal: $245-256$ & Desember 2019 \\
\hline
\end{tabular}

pelaporan tindak kekerasan seksual terhadap anak (Gilbert, Kemp, Thoburn, Sidebotha, Radford, Glasser, \& MacMillan, 2018).

Oleh sebab itu, keluarga perlu ditingkatkan kemampuannya untuk menciptakan lingkungan yang mendukung untik dapat merespon pengungkapan kekerasan seksual yang dialmi anak serta memfasilitasi akses terhadap layanan yang relevan bagi korban. Menurut Jonzon \& Lindlblad (2004) respon yang positif dan mendukung ditandai dengan menunjukkan perhatian yang sungguh-sungguh pada anak, bersikap empatik dan mempercayai anak, tidak menyalahkan serta tidak menganggap enteng pengalaman anak.

\section{Komunitas}

Kondisi komunitas mempengaruhi pengungkapan kekerasan seksual yang dialami anak. Menurut Alaggia dkk. (2017) ketersediaan dan akses layanan yang relevan di lingkungan sekolah maupun luar sekolah untuk anak dan penanganan kekerasan seksual dapat menjadi pintu masuk bagi korban untuk melaporkan kekerasan seksual yang dialaminya. Termasuk di dalamnya bentuk-bentuk program yang dialogis, yang memberikan kesempatan bagi anak-anak untuk mengungkapkan permasalahan pribadinya melalui diskusi, hubungan terapetik, informasi dan edukasi tentang seksualitas serta programprogram pencegahan kekerasan seksual. Selain melalui jalur professional, keberadaan saksi atau active bystander di lingkungan komunitas juga menjadi faktor yang dapat memperkuat atau mendukung korban untuk melaporkan kasus yang dialaminya

Masih menurut Alaggia dkk. (2017), kondisi lingkungan keketanggaan dan komunitas dapat menghambat pengungkapan manakala lembaga pendidikan tidak terlibat dalam menyediakan lingkungan yang mendukung. Anakanak yang mengalami kekerasan seksual juga mengalami hambatan dalam mengungkapkan peristiwa yang mereka alami jika merasa atau menduga bahwa pengungkapan mereka tidak dipercaya oleh lingkungan komunitasnya (tetangga atau anggota komunitas lainnya)

\section{Masyarakat}

Di level masyakat, nilai-nilai yang berakar dari norma budaya dan agama dipandang berpengaruh terhadap pengungkapan kekerasan seksual pada anak. Fontes dan Plummer (2010) mendidkusikan secara panjang lebar bagaimana budaya mempengaruhi tingkat pengumgkapan kekerasan seksual anak, respon korban dan keluarga serta masyarakat secara luas terhadap peristiwa kekerasan seksual. Menurut mereka, di dalam masyarakat di mana aspek mengenai seksualitas dianggap sesuatu yang tabu untuk didiskusikan secara terbuka atau nilai-nilai yang mensubordinasi perempuan, korban umumnya mengalami hambatan untuk melakukan pengungkapan kekerasan seksual. Termasuk di dalamnya nilai-nilai mengenai perasaan malu, keperawanan anak perempuan, nama baik keluarga, keistimewaan kedudukan laki-laki 


\begin{tabular}{|c|c|c|c|c|}
\hline $\begin{array}{c}\text { Focus: Jurnal } \\
\text { Pekerjaan Sosial }\end{array}$ & ISSN: $2620-3367$ & Vol. 2 No: 2 & Hal: $245-256$ & Desember 2019 \\
\hline
\end{tabular}

dalam keluarga atau subordinasi status perempuan.

Misalnya, menurut Fontes dan Plummer (2010), di masyarakat tertentu, aspek kekerasan seksual dapat menyebabkan munculnya rasa malu, termasuk malu untuk melibatkan aparat yang berwenang dan malu atas penilaian teman dan tetangga. Pelaku memanfaatkan perasaan malu yang dimiliki anak untuk menekan korban tidak mengungkapkan kekerasan seksual yang mereka alami. Selanjutnya, di berbagai masyarakat, keperawanan perempuan dipandang sebagai sesuatu yang sakral sehingga ketika seorang anak mengalami kekerasan seksual yang berpotensi merusak selaput daranya, maka ia dipandang tercemar. Akibatnya pengungkapan kasus kepada pihak yang berwenang cenderung dihindari karena dipandang akan menimbulkan aib bagi keluarga atau merusak prospek korban untuk menikah pada saat dewasa. Dalam beberapa budaya, anak perempuan yang mengalami serangan seksual, atas justifikasi membersihkan nama baik keluarga, justru menerima perlakuan kekerasan lain dari anggota keluarga, bahkan berpotensi mengalami kematian.

Misalnya, studi Abu-Baker (2013) terhadap reaksi orangtua berlatar belakang budaya Arab terkait kekerasan seksual pada anak menunjukkan bahwa keluarga Arab akan menolak memperkarakan kekerasan seksual anak secara huku dan memfokuskan pada penyelesaian yang melindungi kepentingan terbaik keluarga, bukan anak. Norma-norma budaya terkait " sexual sin" dan "honour crimes" ditambah dengan loyalitas terhadap keluarga besar membungkam dan menutupi pengungkapan anak atas kekerasan seksual yang dialaminya.

Di budaya lainnya, ekspektasi jender mengenai status anak perempuan juga dapat menjadi fator yang menghambat pengungkapan atau pelaporan kekerasan seksual. Menurut Fontes dan Plummer (2010), di kalangan komunitas kulit hitam Amerika misalnya, perempuan dituntut untuk menanggung beban seberat apapun tanpa mengeluh. Akibatnya, pengungkapan kasus kekerasan kepada pihak yang berwenang tidak didorong karena nilai-nilai budaya mengharapkan korban untuk tidak menyebarluaskan beban yang dialaminya.

Sebaliknya, menurut Alaggia dkk. (2016), konteks lingkungan dan budaya yang mendengar dan menghargai "suara" anak, mendukung diskusi terbuka tentang seksualitas serta keterlibatan anggota komunitas dalam mencegah dan merespon kekerasan seksual menjadi faktor yang dapat mendorong pengungkapan kejadian kekerasan seksual. Faktor-faktor ini berperan dalam mengurangi stigma yang dilekatkan kepada korban tindak kekerasan seksual, menciptakan jaminan perlindungan komunitas terhadap korban dan penghukuman pelaku.

\section{KESIMPULAN}

Kekerasan seksual terhadap anak merupakan pelanggaran hak asasi anak untuk 


\begin{tabular}{|c|c|c|c|c|}
\hline $\begin{array}{c}\text { Focus: Jurnal } \\
\text { Pekerjaan Sosial }\end{array}$ & ISSN: $2620-3367$ & Vol. 2 No: 2 & Hal: $245-256$ & Desember 2019 \\
\hline
\end{tabular}

mendapatkan perlindungan dari segala bentuk kekerasan. Tindak kekerasan terhadap anak tidak hanya berdampak negatif dalam jangka pendek terhadap tumbuh kembang anak namun juga jangka panjang setelah korban menjalani kehidupan sebagai individu dewasa. Kekerasan seksual juga menimbulkan dampak negatif multidimensi: fisik, sosial, psikologis dan ekonomi.

Dampak negatif kekerasan pada korban dapat diminimalisir dengan cara memberikan intervensi yang tepat sesegera mungkin kepada korban. Hal ini dapat difasilitasi jika kekerasan yang dialami anak diketahui dan dilaporkan sedini mungkin kepada penyedia layanan. Namun demikian, berbagai faktor pada level individu dan lingkungan sosial anak mempengaruhi peluang terungkapnya atau terlaporkannya tindak kekerasan seksual yang dialami anak. Lingkungan sosial, utamanya keluarga, lembaga pendidikan, lingkungan ketetanggaan, dan lembaga kemasyarakatan memegang peran penting dalam memberikan dukungan kepada korban untuk mengungkapkan dan melaporkan peristiwa kekerasan seksual terhadap anak.

\section{Referensi}

Abu-Baker, K. (2013). Arab parents' reactions to child abuse: a review of clinical records. Journal of Child Sex Abuse, 22, 52 -71.

Alaggia, R., Collin-Vezine, D., \& Lateef, R. (2016). Facilitating and barriers to child sexual abuse (CSA) disclosures: A research update (2000-2016). Trauma, Violence and Abuse, $X X(X), 1-24$.

Currie, J. \& Widom, C.S. (2010). Long-term consequences of child abuse and neglect on adult economic well-being. Child Maltreatment, DOI: 10.1177/1077559509355316.

Fontes, L.A. \& Plummer, C. (2010). Cultural issues in disclosure of child sexual abuse. Journal of Child Sexual Abuse, 19, 491-518.

Hillis, S.D., Mercy, J.A. \& Saul, J.R. (2016): The enduring impact of violence against children, Psychology, Health \& Medicine, DOI: $10.1080 / 13548506.2016 .1153679$.

Jonzon, E. \& Lindblad, F. (2004). Disclosures, reactions and social support: Findings from a sample of adult victims of child sexual abuse. Child Maltreatment, 9 (2), 90-200.

Mian, M., Wehrspann, W., Klajner-Diamond, H., Labaron, D. \& Winder, C. (1986). Review of 125 children 6 years of age and under who were sex ually abused. Child Abuse \& Neglect, 4:223-229.

UNICEF. (2014). Hidden in plain sight: $A$ Statistical analysis of violence against children. New York: UNICEF. 


\begin{tabular}{|c|c|c|c|c|}
\hline $\begin{array}{c}\text { Focus: Jurnal } \\
\text { Pekerjaan Sosial }\end{array}$ & ISSN: $2620-3367$ & Vol. 2 No: 2 & Hal: $245-256$ & Desember 2019 \\
\hline
\end{tabular}

United Nations Secretary General. (2006). An End to violence against children. New York.
World Health Organization. (2002). World report on violence and health. Geneva: WHO. 